\title{
Acts of terrorism as a crime against humanity in the aspect
}

\section{Of law and human rights}

\author{
Aulia Rosa Nasution \\ Lecturer of Postgradute in Legal Studies, Medan Area University \\ Medan,Indonesia \\ Email: Nasution82auliarosa@gmail.com
}

\begin{abstract}
Terrorism has become a worldwide phenomenon today. Acts of terrorism can be classified as a crime against humanity, which threatens and endangered the peace and the security of mankind. The acts of terrorism are also threatening the human civilization. The purpose of this study is to analyze the acts of terrorism as a crime against humanity in the aspect of law and human rights. This study is using statute approach, legal doctrines and regulations which related to the acts of terrorism and crime against humanity. The first section is the introduction which explains about the definitions of terrorism, the elements of terrorism, and the classification of terrorism. The second section will review the crimes against humanity. The third section will discuss about the acts of terrorism as a crime against humanity in the aspect of law and human rights. The fourth section is theconclusion.
\end{abstract}

Keywords: Acts of Terrorism, Crime Against Humanity, Human Rights, International Criminal Court, Violations

\section{INTRODUCTION}

\section{A.Definitions of Terrorism}

Terrorism has become one of the global issues since the incidents of September 11, 2001, in World Trade Centre which threatened and endangered the peace and security of mankind. The word ofterrorism referring to the system of intimidation and repression implemented by the Jacobins (the ' Red Terror' or ' Reign of Terror') in the Frech Revolution. Terrorism also used as an instrument of State control. For example:Bismark "terrorized" Prussia by using the army as a means of social control; NAZI Germany imposedreign of terror across Europe and Allied air forces resorted to 'terror bombing' in the Second World War, and Stalin ruled Russia by terror". Gradually terrorism also came to refer to non - State practices. In the late nineteenth century, revolutionaries and anarchists in tsarist Russia were commonly known as terrorist. The Bolshevik seizure of power is oftendescribed as revolutionary terror and communist embraced terrorism as a means of class struggle. Terrorism internationally condemned as the unlawful use and the manifestation of political movement. But in October 2004 the UN Security Council unanimously passed Resolution 1566 which defines terrorism and declares that in no circumstances can terrorist acts be condoned or excused for political or ideological reasons;
Criminal acts, including those against civilians, committed with the intent to cause death or serious bodily injury or taking of hostages with the purpose to provoke a state of terror in the general public or in a group of persons or particular persons, intimidate a population or compel a government or an international organization to do or to abstain from doing any act, which constitue offences within the scope of and as defined in the international conventions and protocols relating to terrorism, are under no circumstances justifiable by considerations of a political, philosophical, ideological, racial, ethnic, religious or other similar nature.

Terrorism can be conceptually and empirically distinguished from other modes of violence and conflict by the following characteristics; a) it is premeditated and designed to create a climate of extreme fear; b) it is directed at a wider target than the immediate victis; c) it inherently involves attacks on random or symbolic targets, including civilians; d) it is considered by the society in which it occurs as 'extra-normal' that violates the norms; e) it is used primarily to influence the political behavior of governments, communities or specific social groups.

There are many definitions of terrorism but no universally accepted definition of terrorism until now, even the United Nation agencies haven't succeeded in making the official definition of terrorism. Noam Chomsky said that the term of 
terrorism began to used in the end of the $18^{\text {th }}$ century which shows the actions of violence from the ruling government in order to ensure that the people will obey the government. In other words, the term of terrorism refers to coercion from the ruling government. Walter Lacquer said that terrorism is the unlawful use of force for political purposes which targeting many civilian population; Walter Reich said that terrorism is a strategy of violence which designed to achieve certain desires from anindividual or certain groups by means of terror to frighten the public in large scale. Meanwhile, Brian Jenkins said that terrorism is the unlawful use of force which designed to achieve the political purposes.

From those definitions, we can identify the main component of terrorism. First, the use of unlawful force.Second, the actors which led by state actors or non state actors. Third, acts of terrorism is using the unconventional methods. Forth, commited the attack to the civilian population and targeting the military objects. Fifth, the act of terrorism aimed to influence the audience. Historically, the definitions of terrorism are compiled in international conventions of terrorism. According to article 1 paragraph (2) of the International Convention from League of Nation , 1937 which stated that terrorism is the criminal acts directed against a State and intended or calculated to create a State of terror in the minds of particular persons or a group of persons or the general public. A better definition of terrorism can be seen in the International Convention for the Suppression of Terrorist Bombings, 1997 in article 2 paragraph (1) :

Any person commits an offence within the meaning of this Convention if that person unlawfully and intentionally delivers, places, discharges or detonates an explosive or other lethal device in, into or against a place of public use, a State or government facility, a public transportation system or an infrastructure facility: (a) with the intent to cause death or serious bodily injury; or (b) with the intent to cause extensive destruction of such a place, facility or system, where such destruction results in or is likely to result in major economic loss.

The definition of terrorism in the UK Legislation is contained in the Terrorism Act (2000) stated that terrorism as the use or threat of action where the action falls within if it a) involves serious violence against a person; b) involves serious damages to property; c) endangers a person's life, other than that of the person committing the action, d) creates a serious risk to the health or safety of the public or a section of the public; or e) is designed seriously to interfere with or seriously to disrupt an electronic system. Terrorism also means the use or threat which is designed to influence the government or to intimidate the public or a section of the public and the use or threat is made for the purpose of advancing a political, religious or ideological cause.

The definition of terrorism has been stated also in other twelve international conventions of terrorism. On the other hand, the UN Security Council has issued four UN Resolution which related to international terrorism. The UN Security Council Resolution No. 1368 which issued at September 2001 and UN Security Resolution No. 1373 issued at October $15^{\text {th }}, 2002$, has insisted all countries totake action to respond the terrorist attacks. The UN Security Council Resolution No. 1373 and No. 1438 also expressed condolences and deep sympathy for the government and the people of Indonesia, for all victims and its family and insisted many countries in the world to fight against terrorism and called the entire nations to work together to help Indonesia in finding and prosecuting the perpetrators of terrorism to justice.

Terrorism can be divided to two parts. The first part is State Terrorism or State Sponsored Terrorism, and the second part is a Non-State Terrorism. State Terrorism is a use of terror by a government as an instrument to subjugate other party to achieve governments purposes. State Terrorism oftenoccurred in the authoritarian and repressive government. In other words, this kind of authoritarian and repressive government always using terror as their instrument to intimidate anyone against their policies. State Sponsored Terrorism can be transformed into transnational crime if a country commits acts of terror against other countries by giving assistance, protection, financing plan, and facilitating terrorist group to other countries. For example, State Terrorism in Adolf Hitler authoritarian regime in Germany and Joseph Stalin totalitarian government in Uni Soviet which commits many acts of terror like kidnapping, punishing, torturing, and executing many innocent civilian which make a lot of people 
terrified. On the other hand, Non-State Terrorism is a terror used by non-State actor by individual or certain group of people against the people or government with any motives behind. For example, the terrorist group of Bali Bombing which was led by Imam Samudera, the terrorist group of Noordin M. Top from Jemaah Islamiyah, the terrorist Group of Santoso which commits many acts of terrorism in Sulawesi, and also the terrorist group of $\mathrm{Abu}$ Sayyaf who commits murder and hostages in the south areas of Philippine.

\section{CRIME AGAINST HUMANITY}

\section{A. The Definition of Crime Against Humanity}

The term of a crime against humanity was first recognized in the joint declaration between France, United Kingdom and Russia on 24th of May, 1915. This declaration was intended to condemn the Turkish atrocities that have been made during the war against Armenians in Turkey. This massacre of Armenia's population known as a 'crime against humanity'. The 1945 Charter of the Military Tribunal at Nuremberg identified three classes of international crime; a) crime against peace; b) war crimes ; c) crimes against humanity. Even the Statute of International Criminal Court list four categories of crimes to be prosecuted by the ICC ; a) the crime of genocide; b) the crime of aggression; c) war crimes and crimes against humanity. Crime against humanity usually done in a systematic way and causing physical or mental suffering,or killing of human beings that are contrary to human civilization as well as violating the principles of international law. Crime against humanity is a criminal act which creates the condition of individuals and communities in an atmosphere of terror. In the perspective of human rights, crimes against humanity can be classified to gross violation of human rights, if the acts committed as part of a 'widespread' and 'systematic' attack, directed against the civilian population, which is committed against innocent civilians like the Bali bombing incidents. Crime against humanity was known for the first time in the London Charter of the International Military Tribunal, 1915, which resulted the Nuremberg Trial that prosecuted the German NAZI war criminals. In the Article 6 (c) of Nuremberg Charter, crime against humanity is defined as murder, extermination, enslavement, deportation and other inhuman acts committed against any civilian population, before or during the war, or persecutions on political, racial or religious grounds in execution of or in connection with any crime within the jurisdiction of the Tribunal, whether or not in violation of the domestic law of the country where perpetrated. In the Judgment of the International Military Tribunal for the Trial of German Major War Criminals it was also stated that the Tribunal therefore cannot make a general declaration that the acts before 1939 were crimes against humanity within the meaning of the Charter, but from the beginning of the war in 1939 war crimes were committed on a vast scale, which were also crimes against humanity; and insofar as the inhumane acts charged in the indictment, and committed after the beginning of the war, did not constitute war crimes, they were all committed in execution of, or in connection with, the aggressive war, and therefore constituted crimes against humanity.

\section{B. The Elements of Crime Against Humanity}

Crimes against humanity completely and clearly stated in the Statute of the International Criminal Court (ICC) which known as the Rome Statute, 1998. In the article 7 of the Statute, crime against humanity defined as any of the following acts when committed as part of a widespread or systematic attack directed against any civilian population, with knowledge of the attack: (a) murder; $\begin{array}{ll}\text { (b) extermination; } & \text { (c) enslavement; }\end{array}$ (d) deportation or forcible transfer of population; (e) imprisonment or other severe deprivation of physical liberty in violation of fundamental rules of international law; (f) torture; (g) rape, sexual slavery, enforced prostitution, forced pregnancy, enforced sterilization, or any other form of sexual violence of comparable gravity; (h) persecution against any identifiable group or collectivity on political, racial, national, ethnic, cultural, religious, gender as defined in paragraph 3 , or other grounds that are universally recognized as impermissible under international law, in connection with any act referred to in this paragraph or any crime within the jurisdiction of the Court; (i) enforced disappearance of persons; (j) the crime of apartheid; (k) other inhumane acts of a similar character intentionally causing great suffering, or serious injury to body or to mental or physical health. Crimes Against Humanity can be done in times of peace, as well as during internal wars and 
international wars .Thus, from the formulation of Article 7 we can see that the Rome Statute of 1998 already contained the basics of an act or acts that qualify as crimes against humanity which condemned by the international community as a crime against human civilization (HostisHumanis Generis).

\section{ACTS OF TERRORISM AS A CRIME AGAINST HUMANITY IN THE ASPECT OF LAW AND HUMAN RIGHTS}

\section{A.Terrorism as a Crime Against Humanity}

Terrorism is a crime, a crime against humanity as a whole. It is a crime against the whole world no matter who, what or which country has been or is being targeted. The attacks on September 11 affect the whole world and damages not just buildings in a particular country and the people in them. It has shattered the confidence of the world and has left an atmosphere of fear. According to the international criminal law system, the law enforcement system for international crime can be divided in two categories; a) Direct enforcement system and b) Indirect enforcement system. Direct Enforcement System is an international criminal law enforcement which is conducted by the International Criminal Court (ICC) permanently or temporarily. The ICC ia a permanent international court that was established on July 17, 1998 by the Rome Statute, which was passed through voting by 148 countries, of which 120 countries voted in favor, 7 opposed and 21 countries abstained including Indonesia. Among the 7 countries who opposed are United States, China and Irak. More than 108 countries have ratified the Rome Statute of 1998. The ICC is an international court that initiated by the United Nations, which located in Den Haag, Netherland. There are around 15 to 20 judges from various nations who carried out their duty. According to Article 4 paragraph (1) of this Statue, the ICC haveinternational legal capacity which means that the court has a position as a subject of international law. The ICC also have national legal capacity, which means that the ICC has a legal status either as subjects of international law as well as the subject of the national law in the territory of the participant and nonparticipant countries. The ICC criminal jurisdiction includes 4 crimes which stated in the Article 5 of the Statute as follows; a) Crime of aggression; b) Genocides; c) Crimes Against Humanity; d) War Crimes. The first principles of ICC is a complementary principle. The complementary principle means that if the crime was part of ICC's jurisdiction, the ICC will submit it to the national legal system of the country where the crime occurred. If a country is unwilling or unable to prosecute then the ICC can prosecute the crime. The complementary principle also means that a state may request an assistance from other countries to cooperate in dealing with crimes such as extradition. The existence of complementary principles are influenced by four factors as follows; a) mutual interest; b) national sovereignty; c) humanistic and humanitarian values; d) needs of world order. The second principle is the principle of legality. The principle of legality in international criminal law should be able to maintain the harmony, the social justice and the world order. The third principle is 'nebis in idem'. It's a legal doctrine to the effect that no legal action can be instituted twice for the same cause of action. But this principle can't be applied absolutely, which means the ICC can prosecute all crimes within the ICC jurisdiction if the national court unable to run the judicial process fairly. In other words, the ICC shouldn't play a role if the national court began to investigate and examine those crimes. The fourth principle is the individual criminal responsibility. The term 'individual criminal responsibility ' is also commonly employed to describe the scenario where an individual is criminally responsible for his own unlawful actions as opposed to being criminally responsible for the unlawful actions of others, namely 'collective criminal responsibility'.

\section{B.Terrorism as a Violation of Human Rights}

Terrorism is generally understood as acts of violence which spread terror among the civilians and civilian population. Terrorist use terror as their weapon. The hijacking and crashing of the aircrafts create terror in the minds of people, especially the direct and indirect victims. Such is the fear created that people now afraid to fly. The Abu Sayyaf kidnappers inspire fear by beheading their hostages. Exploding bombs in public places and killing innocent people inspire fear and terror, and a feeling of being unsafe anywhere at any time.Terrorismis aserious humanrights violation; undermines the State and peaceful political processes; and threatens international peace and security. Numerous resolutions of the UN General Assembly since the 1970's, and of the Commission on Human Rights since the 1990's assert that 
terrorism threatens or destroys basic human rights and freedoms, particularly life, liberty and security but also civil and political and economic, social and cultural rights. Regional anti terrorism instrumentsuch as 1998 Arab Convention,preamble; 1999 OIC Convention, preamble; 1971 OAS Convention, preamble; 1999 OAU Convention, preamble, OAS Declaration of Lima to Prevent, Combat and Eliminate Terrorism, 26 April 1996, preamble also stated that terrorism gravely violates human rights. UN Special Rapporteur observes that there is probably not a single human rights exempt from the impact of terrorism. Terrorism clearly has a very real and direct impact on human rights, with devastating consequences for the enjoyment of the right to life, liberty and physical integrity of victims. In addition to these individual costs, terrorism can destabilize Governments, undermine civil society, jeopardize peace and security, and threaten social and economic development. All of these also have a real impact on the enjoyment of human rights. Human rights are universal values and legal guarantees that protect individuals and groups against actions and omissions primarily by State agents that interfere with fundamental freedoms, entitlements and human dignity. The full spectrum of human rights involves respect for, and protection and fulfillment of, civil, cultural, economic, political and social rights, as well as the right to development. Human rights are universal-in other words, they belong inherently to all human beings-and are interdependent and indivisible. According to the opinion of MochtarKusumaatmadja and B. AriefSidharta, the definition of human rights basically is freedom to do something or not to do something related to the subject without interference from any party and those freedoms are recognized and have protected by law and therefore have a legal basis. The human rights norms based on the idea that the people must be freed from the cruel and inhumane acts. Every human has three kinds of human rights, 1) the right to live, 2) the right for freedom, 3) the right to have something.

The Universal Declaration of Human Rights (UDHR) preamble states that 'freedom from fear' is part of 'the highest aspiration of the common people' while the International Covenant on Civil and Political Rights (ICCPR) and the International Covenant on Economic, Social and Political Rights (ICESCR) preambles refer to the ideal of free human beings enjoying freedom from fear'. The political ideal of 'freedom from fear' was first articulated as one of four freedoms in a speech by US President Franklin D. Roosevelt in 1941. Franklin D. Roosevelt stated the Four Freedom which was known as "the four freedom speech" (1941 State of the Union Address) where he proposed four fundamental freedoms that people everywhere in the world ought to enjoy as follows; a) freedom of speech, b) freedom of worship,c) freedom from want ; d) freedom from fear. The four freedoms of Roosevelt formed an important pillar of the Universal Declaration of Human Rights that were adopted on December 10, 1948 by United Nation General Assembly. The freedom from fear is mentioned in the preamble of the Declaration. Universal Declaration of Human Rights is considered fundamental human rights document and binding on all states. International human rights law has been codified through major human rights treaties and the remaining portion is available in customary international law. The most important of these treaties are, International Covenant on Economic, Social and Cultural Rights; and the International Covenant on Civil and Political Rights, and its two Optional Protocols. Modern human rights standards are rooted in the following four simple values ; a) freedom of want,b) fredom of fear; c) freedom of belief, d) freedom of expression. These freedoms form the core principles of the Universal Declaration of Human Rights which set out the fundamental elements of international human rights accepted United Nations member states and elaborated in many subsequent human rights treaties. This declaration is accepted as "a common standard of achievement for all people and all nations".

Terrorism aims at the very destruction of human rights, democracy and the rule of law. It attacks the values that lie at the heart of the Charter of the United Nations and other international instruments: respect for human rights; the rule of law; rules governing armed conflict and the protection of civilians; tolerance among peoples and nations; and the peaceful resolution of conflict. Terrorism has a direct impact on the enjoyment of a number of human rights, in particular the rights to life, liberty and physical integrity. Terrorist acts can destabilize Governments, undermine civil society, jeopardize peace and security, threaten social and economic development, and may especially negatively affect certain groups. All of 
these have a direct impact on the enjoyment of fundamental human rights. The destructive impact of terrorism on human rights and security has been recognized at the highest level of the United Nations, notably anthe new Human Rights Council which states have set out that terrorism: a) threatens the dignity and security of human beings everywhere, endangers or takes innocent lives, creates an environment that destroys the freedom from fear of the people, jeopardizes fundamental freedoms, and aims at the destruction of human rights;b) has an adverse effect on the establishment of the rule of law, undermines pluralistic civil society, aims at the destruction of the democratic bases of society, and destabilizes legitimately constituted Governments; c) has links with transnational organized crime, drug trafficking, money-laundering and trafficking in arms, as well as illegal transfers of nuclear, chemical and biological materials, and is linked to the consequent commission of serious crimes such as murder, extortion, kidnapping, assault, hostagetaking and robbery; d) has adverse consequences for the economic and social development of States, jeopardizes friendly relations among States, and has a pernicious impact on relations of cooperation among States, including cooperation for development; and e) threatens the territorial integrity and security of States, constitutes a grave violation of the purpose and principles of the United Nations, is a threat to international peace and security, and must be suppressed as an essential element for the maintenance of international peace and security. International and regional human rights law makes clear that States have both a right and a duty to protect individuals under their jurisdiction from terrorist attacks. This stems from the general duty of States to protect individuals under their jurisdiction against interference in the enjoyment of human rights. More specifically, this duty is recognized as part of States' obligations to ensure respect for the right to life and the right to security.The right to life, which is protected under international and regional human rights treaties, such as the International Covenant on Civil and Political Rights, has been described as "the supreme right" because without its effective guarantee, all other human rights would be without meaning. As such, there is an obligation on the part of the State to protect the right to life of every person within its territory and no derogation from this right is permitted, even in times of public emergency.The protection of the right to life includes an obligation on States to take all appropriate and necessary steps to safeguard the lives of those within their jurisdiction. As part of this obligation, States must put in place effective criminal justice and law enforcement systems, such as measures to deter the commission of offences and investigate violations where they occur; ensure that those suspected of criminal acts are prosecuted; provide victims with effective remedies; and take other necessary steps to prevent a recurrence of violations.In addition, international and regional human rights law has recognized that, in specific circumstances, States have a positive obligation to take preventive operational measures to protect an individual or individuals whose life is known or suspected to be at risk from the criminal acts of another individual,which certainly includes terrorists. Also important to highlight is the obligation on States to ensure the personal security of individuals under their jurisdiction where a threat is known or suspected to exist. This, of course, includes terrorist threats.

\section{CONCLUSION}

The conclusions of this study are as follows. First, acts of terrorism can be classified as a crime against humanity which is conducted systematically or widespread, and organized by State or non-State actor directed to any civilian people. Secondly, for most countries, acts of terrorism are criminalized as an ordinary crime, but this crime has killed many innocent people, civilians or military officer, and organized by a State or non-State actors which constitute to a crime against humanity. Thirdly, the International Criminal Court has an important role to prosecute acts of terrorism that leads to crimes against humanity. On this concluding section, researcher also suggests few things. First, every nonparticipant country of the ICC Statue (Rome Statute 1998) should sign the Rome Statute immediately which aims to prosecute the perpetrators in the ICC. Second, the Rome Statute of International Criminal Court should add the acts of terrorism as a crime against humanity into its jurisdiction . Third, every country should be able to cooperate in combating terrorism and using the International Criminal Court as one of the legal instrument to respond the acts of terrorism in addition to its domestic law. 


\section{REFERENCES}

[1] Abdussalam , "HukumPidanaInternasional", Penerbit: RestuAgung, Jakarta, (2006)

[2] Ali Mahsyar, "Gaya Indonesia MenghadangTerorisme:

SebuahKritikAtasKebijakanHukumPidanaTerhadap TindakPidanaTerorisme di Indonesia", Penerbit: MandarMaju, Bandung, (2009)

[3] Ben Saul, "Defining Terrorism in International Law", Oxford University Press, Oxford, (2006)

[4] Ciara Damgaard, Individual Criminal Responsibility for the Core International Crimes, Springer-Science and Business Media, www.springer.com/us/book/9783540787808, pp.13

[5] Crime Against Humanity, https://en.wikipedia.org/wiki/Crimes_against_hu manity, Retrieved, 29 August 2016

[6] Countering Terrorism Protecting Human Rights : A Manual, OSCE \& Office for Democratic Institutions and Human Rights (ODIHR) , http://www.osce.org/odihr/29103?download=tru e retrieved on 14 September 2016

[7] Eddy, O.S., Hiearij, "PengadilanatasBeberapaKejahatanSeriusTerhadap $H A M$ ", Penerbit: Erlangga, Jakarta, (2010)

[8] Eddy, O.S., Hiearij, PengantarHukumPidanaInternasional, Penerbit: Erlangga, Jakarta,(2009)

[9] Geoffrey Robertson, Q.C., "Crime Against Humanity: The Struggle for Global Justice",Penguin Book, (2000)

[10] Gus Martin, "Understanding Terrorism, Challenges, Perspectives and Issues",

SAGE Publications, Washington D.C., Cetakan Ke-4, (2013)

[11] I

WayanParthiana,

“HukumPidanaInternasional",Penerbit:

YramaWidya, (2006)

[12] Indriyanto Seno Adjie

"HumanismedanPembaruanPenegakanHukum",

Penerbit :BukuKompas, Jakarta, (2009)

[13] International convention for the Suppression of terrorism, http://www.un.org/en/sc/ctc/docs/conventions/ Conv11.pdf, Retrieved 30 August, 2016

[14] League of Nation of Convention for the Prevention and Punishment of Terrorism, council on foreign relations,http://www.cfr.org/terrorismand-the-law/league-nations-conventionprevention-punishment-terrorism/p24778, Retrieved 29 August, 2016

[15] Lary May, "Crimes Against Humanity: A Normative Account", Cambridge University Press, New York, (2005)

[16] Mahathir Mohammad, Terrorism and The Real Issues, Pelanduk Publications, Malaysia (2003)

[17] Mardenis, "PemberantasanTerorisme: PolitikInternasionaldanPolitikHukumNasional Indonesia", Penerbit: PT Raja GrafindoPersada, Edisi ke-1, Jakarta, (2010)

[18] Max BoliSabon, HakAsasiManusiaBahanPendidikanuntukPergurua nTinggi, UniversitasAtmajaya, (2014)

[19] Muhammad, A.S. Hikam, "Deradikalisasi: PeranMasyarakatSipil Indonesia

membendungRadikalisme", Penerbit: BukuKompas, Jakarta , (2016)

[20] OentoengWahjoe,

"HukumPidanaInternasional

:PerkembanganTindakPidanaInternasionaldan

Proses Penegakannya",Penerbit: Erlangga, Jakarta, (2010)

[21] Office of the United Nations High Commissioner for Human Rights, "Human Rights, Terrorism \&Counter Terrorism", www.ohchr.org/Documents/Publications/Factshe et32EN.pdf, Retrieved on 14 September 2016

[22] Paul Wilkinson, Terrorism versus Democracy The Liberal State Response, Routleged, $2^{\text {nd }}$ Edition (1996)

[23]

RomliAtmasasmita, "HukumPidanaInternasionalDalamKerangk aPerdamaian

danKeamananInternasional",

Penerbit: FikahatiAneska, Jakarta, (2010)

[24] Rome Statute of the International Criminal Court,

http://legal.un.org/icc/statute/99_corr/cstatute.ht m, Retrieved 31 August, 2016 
[25] SaqibJawab, Terrorism and Human Rights, Sociology and Anthropology 3 (2) : 104 -115, http://www.hrpub.org Retrieved 14 September 2016

[26] Terrorism Act 2000, http://www.legislation.gov.uk/ukpga/2000/11/p dfs/ukpga_20000011_en.pdf, Retrieved 21 September 2016

[27] Wikipedia, Four Freedoms, https://en.wikipedia.org/wiki/Four_Freedoms, retrieved 15 September 2016 